\title{
Isolation and Expression Analysis of a SOMATIC EMBRYOGENESIS RECEPTOR-LIKE KINASE (SERK) Gene in Curcuma alismatifolia Gagnep.
}

\author{
Kannaporn Sucharitakul ${ }^{1}$, Rungroj Rakmit ${ }^{2}$, Yada Boonsorn ${ }^{2}$, Oranuch Leelapon ${ }^{2}$, Tharathorn Teerakathiti ${ }^{2}$, \\ Sumontip Bunnag ${ }^{1} \&$ Yindee Chanvivattana ${ }^{2}$ \\ ${ }^{1}$ Department of Biology, Faculty of Science, Khon Kaen University, Khon Kaen, Thailand \\ ${ }^{2}$ National Center for Genetic Engineering and Biotechnology, Pathum Thani, Thailand \\ Correspondence: Yindee Chanvivattana, National Center for Genetic Engineering and Biotechnology, Thailand \\ Science Park, Pathum Thani, 12120, Thailand. Tel: 66(0)-2564-6700. E-mail: yindee@biotec.or.th
}

Received: June 12, 2014 Accepted: July 15, 2014 Online Published: September 15, 2014

doi:10.5539/jas.v6n10p207

URL: http://dx.doi.org/10.5539/jas.v6n10p207

\begin{abstract}
Somatic embryogenesis provides a useful tool to facilitate efficient mass propagation in plants. The SOMATIC EMBRYOGENESIS RECEPTOR-LIKE KINASE (SERK) gene serves a fundamentally important role in somatic embryogenesis of many plant species. The isolation of a SERK gene homolog, namely CaSERK, from Curcuma alismatifolia Gagnep. cv. Blue Tung, was reported. Prediction of coding sequence showed that it encoded a protein of 628 amino acids showing high similarity to previously characterized SERK sequences and containing all the features shared by members of the SERK family, including five leucine-rich repeats and the distinctive proline-rich SPP domain. Investigation of CaSERK expression revealed that its transcripts were found throughout the whole somatic embryogenesis process with highest abundance in embryogenic callus. These results indicate that CaSERK might have somatic embryogenesis-associated functions in this economically important ornamental ginger. Detection of CaSERK transcript accumulation in flower and coma bract tissues is suggestive of its additional roles in other developmental signaling pathways.
\end{abstract}

Keywords: Curcuma alismatifolia Gagnep., SOMATIC EMBRYOGENESIS RECEPTOR-LIKE KINASE (SERK), somatic embryogenesis, gene expression

\section{Introduction}

Members of the Curcuma genus in the monocotyledonous Zingiberaceae family have long been extensively cultivated for culinary and medicinal uses. Recently, however, Curcuma plants have been gaining attention for their ornamental values due to their conspicuous inflorescences. Curcuma alismatifolia Gagnep., known as Siam tulip, summer tulip or Patumma, is a native of Indochina with widespread occurrence throughout Thailand. It bears beautiful inflorescence containing large and colorful coma bracts, making it highly popular in the floriculture market. Due to its economic importance, C. alismatifolia has become a prime ornamental crop of Thailand and a breeding target for novel and improved characteristics (Prathepha, 2000).

C. alismatifolia is mainly vegetatively propagated using its underground rhizomes. However, the propagation rate is considerably slow, which makes the production difficult to keep up with increasing market demands. Moreover, rhizome production is hampered by serious damages caused by wilt disease (Elphinstone, 2005). In this regard, advances in plant biotechnology could provide alternative strategies for an efficient propagation of $C$. alismatifolia. In recent years, somatic embryogenesis has become a promising tool for mass propagation in a wide range of plant species. Establishment of in vitro propagation and regeneration via somatic embryogenesis also provides a platform for genetic engineering of desired traits. The widely recognized single-cell origin of the transformants generated by somatic embryogenesis route is considered advantageous over the traditional regeneration by organogenesis since chimerism is unlikely to occur (Ghosh et al., 2009). However, monocotyledonous plants are generally known to be recalcitrant towards somatic embryogenesis. In the genus Curcuma, there are very few reports to date on protocols for efficient and reliable regeneration system via somatic embryogenesis (Raju et al., 2013; He \& Gang, 2014). Thorough understanding of the genetic mechanisms underlying various aspects of somatic embryogenesis could help overcome the barriers to the 
process and thus lead to successful implementation of the technology in in vitro propagation of Curcuma species, including C. alismatifolia.

The SOMATIC EMBRYOGENESIS RECEPTOR-LIKE KINASE (SERK) genes have garnered a lot of research attention due to their taken out pivotal role during somatic embryogenesis in plants. They encode members of the leucine-rich repeat receptor-like kinases (LRR-RLKs), a sub-group of plant RLKs, which are known to be integral to the signal transduction machinery in diverse developmental processes (Cock et al., 2002). The involvement of SERK proteins in regulating somatic embryogenesis was first described for DcSERK in embryogenic cell suspension cultures of carrot more than 15 years ago (Schmidt et al., 1997). Since then SERK gene homologs have been identified and their role in mediating somatic embryogenesis demonstrated in several monocot and dicot species such as Arabidopsis thaliana (Hecht et al., 2001), Medicago truncatula (Nolan et al., 2003), Triticum aestivum (Singla et al., 2008), Vitis vinifera (Maillot et al., 2009), Cocos nucifera (Pérez-Núñez et al., 2009), Ananas comosus (Ma et al., 2012) and Cyrtochilum loxense (Cueva et al., 2012). Moreover, a gymnosperm $S E R K$ homolog has recently been discovered and its association with somatic embryogenesis was shown (Steiner et al., 2012). This finding and the high similarity found among the SERK members strongly suggest that the function of SERKs in embryogenic processes is likely conserved during the evolution of seed plants.

This study attempted to isolate a C. alismatifolia SERK sequence and analyze its predicted protein structure and expression patterns during in vitro somatic embryogenesis and in somatic tissues. The data obtained provides the first information on the molecular control of somatic embryogenesis in the genus Curcuma.

\section{Materials and Methods}

\subsection{Plant Material \& In vitro Cultures}

Curcuma alismatifolia cv. Blue Tung plants grown in the greenhouse from commercially available rhizomes were used as material in this study. In vitro cultures were established using immature inflorescences as explants. The inflorescences were sterilized with $15 \%$ Clorox $^{\circledR}$ and transferred onto MS medium (Murashige \& Skoog, 1962) supplemented with $1 \mathrm{mg} / \mathrm{L} \mathrm{TDZ}$ and $30 \mathrm{~g} / \mathrm{L}$ sucrose for 3 months to generate in vitro plantlets. For shoot multiplication, plantlets were transferred and then subcultured onto MS medium supplemented with $1 \mathrm{mg} / \mathrm{L}$ kinetin and $30 \mathrm{~g} / \mathrm{L}$ sucrose.

\subsection{Establishment of Somatic Embryogenesis}

For embryogenic callus induction, leaf sheath explants $(2.0 \mathrm{~cm}$ long $)$ from 3-month-old in vitro plantlets were placed on MS medium containing $4 \mathrm{mg} / \mathrm{L}$ picloram and $30 \mathrm{~g} / \mathrm{L}$ sucrose for 1 month. Embryogenic calli were converted into plantlets by transferring to half strength MS medium supplemented with $0.2 \mathrm{mg} / \mathrm{L} \mathrm{NAA}, 1 \mathrm{mg} / \mathrm{L}$ BA, $30 \mathrm{~g} / \mathrm{L}$ sucrose, $300 \mathrm{mg} / \mathrm{L}$ casamino acids and $3 \mathrm{~g} / \mathrm{L}$ Kelcogel (CP Kelgo, USA). Somatic embryo development was investigated. Samples from several stages of somatic embryogenesis were collected. For investigation of tissue-specific gene expression, samples were collected from leaves, flowers and coma bracts of blooming plants. All C. alismatifolia samples were immediately frozen in liquid nitrogen and stored at $-80^{\circ} \mathrm{C}$ for later use in RNA isolation.

\subsection{RNA Isolation and cDNA Synthesis}

Total RNA was extracted from embryogenic callus, embryogenic tissues at different stages of somatic embryogenesis and various somatic tissues of C. alismatifolia $\mathrm{cv}$. Blue Tung using PureLink ${ }^{\circledR}$ Plant RNA reagent (Ambion) following the instructions of the manufacturer. The RNA samples were treated with DNase I (Qiagen) to eliminate traces of genomic DNA. Spectrophotometric analysis was performed to determine the concentration of each RNA sample whose integrity was confirmed by $1.2 \%$ agarose gel electrophoresis. First-strand cDNA was prepared using SuperScript ${ }^{\circledR}$ III Reverse Transcriptase (Invitrogen Life Technologies) with oligo (dT) $)_{18}$ primer except for gene expression analysis, in which random pentadecamer primers (Bio Basic, Canada) were employed in the synthesis of cDNA.

\subsection{Cloning of Full-Length cDNA of CaSERK}

A pair of degenerate primers; SERK-F1 \& SERK-R1 (listed in Table 1), were designed based on conserved domains found among plant SERK sequences and used to isolate a fragment of CaSERK in the PCR amplification with cDNA from globular embryos as template. The PCR conditions were as follows; $94{ }^{\circ} \mathrm{C}$ for 3 min, 50 cycles of amplification $\left(94{ }^{\circ} \mathrm{C}\right.$ for $30 \mathrm{~s}, 55^{\circ} \mathrm{C}$ for $30 \mathrm{~s}$ and $72{ }^{\circ} \mathrm{C}$ for $90 \mathrm{~s}$ ) and a final extension at $72{ }^{\circ} \mathrm{C}$ for $5 \mathrm{~min}$. The $5^{\prime}$ end and $3^{\prime}$ end sequences were obtained using the GeneRacer ${ }^{\mathrm{TM}}$ kit (Invitrogen Life Technologies) following the instructions of the manufacturer. In 5'RACE, first round PCR amplification was carried out using a gene-specific primer BT-SERK-R1 and the nested PCR then followed by employing a second 
gene-specific primer BT-SERK-R2. The thermal cycling conditions were $94{ }^{\circ} \mathrm{C}$ for $3 \mathrm{~min}, 35$ cycles of amplification $\left(94^{\circ} \mathrm{C}\right.$ for $30 \mathrm{~s}, 58^{\circ} \mathrm{C}$ for $30 \mathrm{~s}$ and $72{ }^{\circ} \mathrm{C}$ for $90 \mathrm{~s}$ ) and a final extension at $72{ }^{\circ} \mathrm{C}$ for $5 \mathrm{~min}$. Another nested gene-specific primer pair; BT-SERK-F1 \& BT-SERK-F2, were employed in 3'RACE with the amplification program; $94{ }^{\circ} \mathrm{C}$ for $3 \mathrm{~min}, 35$ cycles of amplification $\left(94{ }^{\circ} \mathrm{C}\right.$ for $30 \mathrm{~s}, 58{ }^{\circ} \mathrm{C}$ for $30 \mathrm{~s}$ and $72{ }^{\circ} \mathrm{C}$ for $90 \mathrm{~s}$ ) and a final extension at $72{ }^{\circ} \mathrm{C}$ for $5 \mathrm{~min}$. PCR products of the expected size were cloned into $\mathrm{pCR}^{\mathrm{TM}} 4-\mathrm{TOPO}^{\circledR} \mathrm{TA}$ vector (Invitrogen Life Technologies) and subjected to DNA sequencing. All CaSERK sequences were analyzed and their identities determined by comparison with available sequences in GenBank databases using the BLAST program (http://www.ncbi.nlm.nih.gov). The sequence information obtained was used to design specific primers CaSERKfull-BT1-F1 \& CaSERKfull-BT1-R1 to amplify the full-length CaSERK transcript.

\subsection{Protein Structure and Phylogenetic Analyses}

The open reading frame (ORF) of CASERK was determined using the "ORF Finder" program (http://www.ncbi.nlm.nih.gov/gorf/gorf.html). The presence of a signal peptide and the transmembrane region were predicted using the "SignalP 3.0 Server" (http://www.cbs.dtu.dk/services/SignalP/) and "TMpred" (http://www.ch.embnet.org/software/TMPRED_form.html), respectively. Protein prediction was carried out using Scan Prosite tool (http://prosite.expasy.org/scanprosite/). Multiple sequence alignment of CaSERK with other plant SERK proteins was performed with ClustalW (http://www.genome.jp/tools/clustalw/). A phylogenetic tree was constructed with the MEGA4 software by the neighbor-joining (NJ) method with 1,000 bootstrap replicates.

\subsection{CaSERK Expression Analysis}

Semi-quantitative RT-PCR was performed for the profiling of CaSERK expression at different stages of somatic embryogenesis; namely embryogenic callus, globular embryos, club-shaped embryos, scutellum-shaped embryos and plantlets, as well as leaf, flower and coma bract tissues from intact plants. cDNA samples synthesized from total RNA were normalized against the housekeeping C. alismatifolia 18S rRNA gene (Accession No. KJ921785), then used as templates in amplification reactions using CaSERK-specific primers CaSERK1-F and CaSERK1-R. The PCR procedure was performed under the following non-saturating conditions; an initial denaturation step at $94{ }^{\circ} \mathrm{C}$ for $3 \mathrm{~min}, 29$ cycles of amplification $\left(94^{\circ} \mathrm{C}\right.$ for $30 \mathrm{~s}, 60^{\circ} \mathrm{C}$ for $30 \mathrm{~s}$ and $72{ }^{\circ} \mathrm{C}$ for $30 \mathrm{~s}$ ) and a final extension at $72{ }^{\circ} \mathrm{C}$ for $1 \mathrm{~min}$. Each reaction was done in triplicate. The PCR amplicons were analyzed by running on a $1.4 \%$ agarose gel and visualized using a gel documentation system.

Table 1. Details of primers used in this study

\begin{tabular}{ll}
\hline Description & Primer sequence (5' - 3') \\
Degenerate primers & \\
SERK-R1 & GDT TYC TSC GGC TYA ACA ACA AYA G \\
5'RACE primers & TCH GCM AAR CCA TCW CCT TCA AGC ATT C \\
BT-SERK-R1 & CTT CAG CAG GTA CGT CAA AGA AAT G \\
BT-SERK-R2 & GAA CAA ATG GAG GTG GCG GAG ATA AAG \\
3'RACE primers & \\
BT-SERK-F1 & TGA TGA TGA TGT TAT GTT ACT TGA CTG G \\
BT-SERK-F2 & GAG AAG AAG CTG GAA ATG TTG GTT GAT \\
Full-length cloning & \\
CaSERKfull-BT1-F1 & GAA AAA TGA GCT CTG ATA AAA AAT GAA AGC \\
CaSERKfull-BT1-R1 & ACA TGA ATC CAT TGC TCA TGG ACA AAT C \\
Gene expression analysis & \\
CaSERK1-F & CTC ATA CAA GTG GCT TTG CTA TGC \\
CaSERK1-R & AAC AAA GAT GAA AAT CAT GGA TCA CA \\
18S rRNA-F & GCG ACG CAT CAT TCA AAT TTC TG \\
18S rRNA-R & TGG ATG TGG TAG CCG TTT CTC A \\
\hline & \\
\hline
\end{tabular}




\section{Results}

\subsection{Somatic Embryogenesis and Regeneration}

After one month of callus induction under dim light condition, rapidly proliferating embryogenic calli were derived from leaf sheath explants and numerous calli were produced (Figure 1a). Fresh embryogenic calli were then transferred to regeneration medium. In the first month, formation of globular embryos was initiated (Figure 1b). Later on, active globular embryos entered the transition phase and differentiated into club- and then scutellum-shaped embryos, which are characteristic of monocotyledonous embryos (Figures 1c-1d). Development of mature green somatic embryos then followed (Figure 1e). Subsequently, mature embryos were allowed to germinate into complete plantlets with shoot and root development (Figure 1f). The process of plantlet regeneration via somatic embryogenesis took approximately 6-7 months. Well-developed plantlets were subcultured in MS medium supplemented with kinetin for multiplication and maintenance of in vitro stock (Figure 1g). Samples were taken from embryogenic calli, somatic embryos at different stages and plantlets for CaSERK gene isolation and expression analysis purposes.

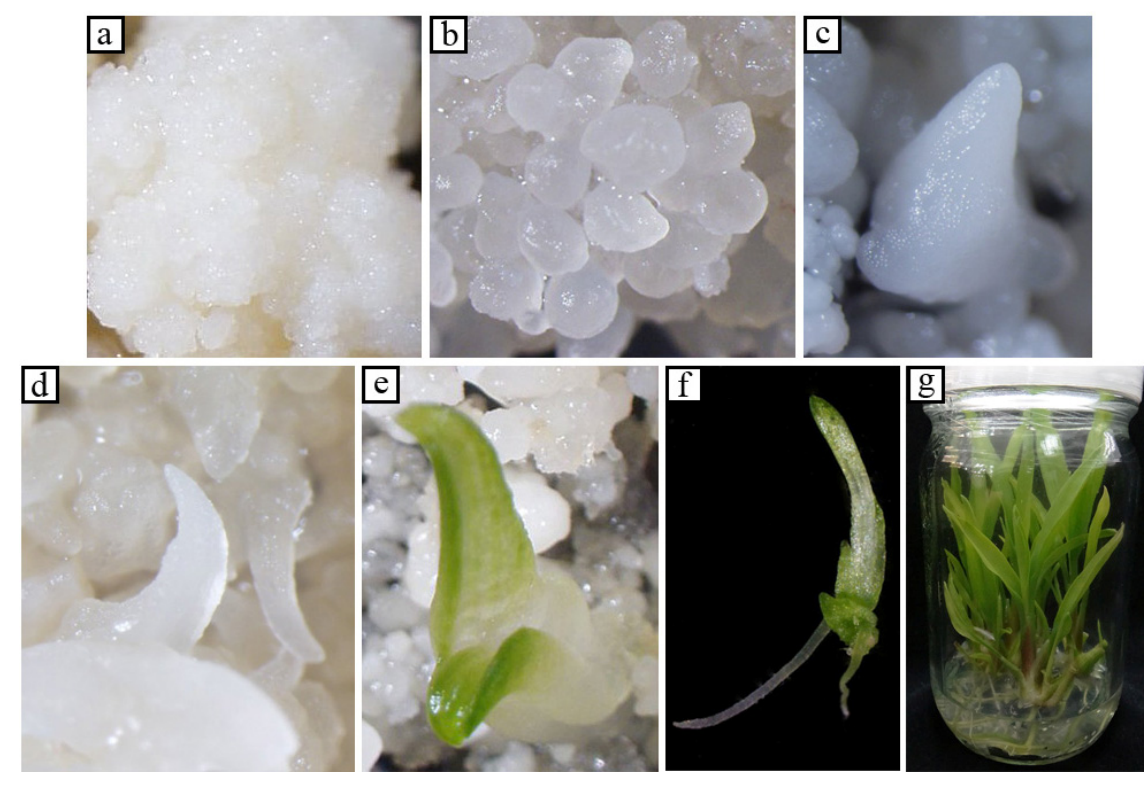

Figure 1. Somatic embryogenesis in Curcuma alismatifolia

(a) embryogenic callus formation; (b) cluster of globular embryos initiated after 1 month of culture on regeneration medium; (c) club-shaped embryo; (d) scutellum-shaped embryos; (e) mature green embryo; (f) plantlet developed via somatic embryogenesis; $(\mathrm{g})$ proliferation of plants derived from somatic embryo.

\subsection{Cloning of CaSERK}

A 1,321 bp SERK fragment was amplified from C. alismatifolia with degenerate primers designed from SERK conserved regions. 5' RACE and 3' RACE reactions were carried out to complete the sequences at 5' and 3' ends, respectively. All fragments were assembled and used to design primers for full-length sequence verification. The corresponding full-length SERK cDNA was designated as CaSERK and its nucleotide sequence was submitted to GenBank under accession number KJ845677. The 2,521 bp of CaSERK sequence consisted of 305 bp of 5'UTR, $1,887 \mathrm{bp}$ of ORF and $329 \mathrm{bp}$ of 3'UTR. The ORF was found to encode a putative protein of 628 amino acids in length, with an estimated molecular weight of $69.54 \mathrm{kDa}$ and a predicted $\mathrm{pI}$ of 5.48 .

Comparison at the protein level revealed that CaSERK showed high identity to other characterized plant SERK sequences such as CnSERK (92\%; Accession No. AAV58833.2), AcSERK2 (91\%; AEC46976.1), OsSERK1 (91\%; NP_001061108.1), HvSERK (88\%; ABN05373.1), AtSERK1 (85\%; NP_177328.1) and MtSERK1 (85\%; AAN64293.1).

\subsection{Analysis of CaSERK Sequence}

Multiple sequence alignment analysis showed that CaSERK contained all the characteristic features of the SERK 
family, including an extracellular domain containing an N-terminal signal peptide, a leucine zipper, five leucine-rich repeats (LRR), a proline-rich SPP region containing the SPP motif, a transmembrane (TM) domain, an intracellular kinase domain and a C-terminal domain (Figure 2); (Hecht et al., 2001). The SPP domain located next to the last LRR is a distinctive presence unique to SERK proteins. The schematic illustration depicting the organization of conserved structural domains in CaSERK is shown in Figure 3a.

Analysis of the signal peptide sequence at the amino terminal by SignalP indicated a possible cleavage site between positions 28 and 29 (Figure 3b). The presence of a putative TM spanning from amino acid residues 243 to 265 was revealed according to transmembrane topology prediction by TMpred (Figure 3c). In the kinase domain of CaSERK, a possible protein kinase ATP-binding region was found between amino acid residues 311 and 333. Additionally, a serine/threonine protein kinase active-site signature between amino acid residues 428 and 440 and an activation-loop (A-loop) region between amino acid residues 449 and 478 were also predicted. The 29 amino acid residues of the A-loop region of CaSERK were 100\% identical to the AtSERK1 counterpart which was demonstrated to be the active site of AtSERK1 (Shah et al., 2001).

\subsection{Phylogenetic Analysis}

The evolutionary relationships between CaSERK and other SERKs were inferred by a phylogenetic tree (Figure 4) constructed based on the alignment of full-length amino acid sequences. The tree represented two subfamilies; plant SERK1/2 and SERK3/4/5. The SERK1/2 clade was further divided into 3 sub-clades; monocotyledonous plant SERK, dicotyledonous plant SERK and gymnosperm SERK. CaSERK was, expectedly, placed inside the monocot sub-clade with closest alliance to CnSERK from C. nucifera. 


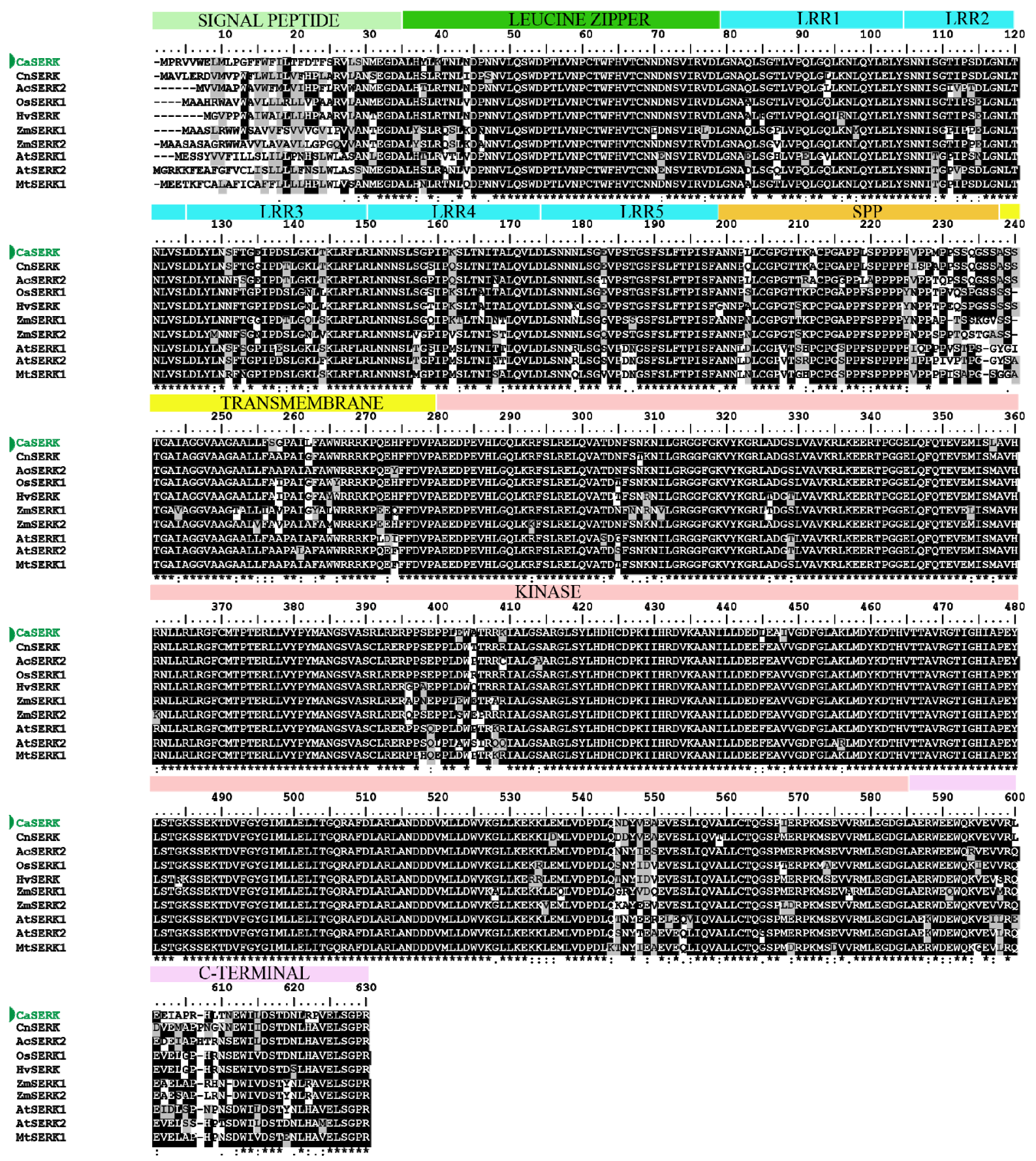

Figure 2. Sequence alignment of predicted amino acid sequences of CaSERK with other plant SERK family protein kinases

Accession numbers of SERK sequences used in the alignment are as follows: CnSERK (Cocos nucifera), AAV58833.2; AcSERK2 (Ananas comosus), AEC46976.1; OsSERK1 (Oryza sativa), NP_001061108.1; HvSERK (Hordeum vulgare), ABN05373.1; ZmSERK1 (Zea mays), NP_001105132.1; ZmSERK2, NP_001105133.1; MtSERK1 (Medicago truncatula), AAN64293.1; AtSERK1 (Arabidopsis thaliana), NP_177328.1; AtSERK2, NP_174683.1.

\subsection{Expression Study}

Expression profile of CaSERK was studied using semi-quantitative RT-PCR. Transcript levels were determined during somatic embryogenesis and also in leaf, flower and coma bract tissues (Figure 5). The results showed that CaSERK was expressed in all stages of somatic embryogenesis examined, although at varying levels. Highest 
expression was detected in embryogenic callus. Subsequently, the expression decreased at early embryo-transition phase in globular and club-shaped embryos. Further down-regulation was observed during later stages of somatic embryogenesis in scutellum-shaped embryos and plantlets. Analysis of CaSERK transcript accumulation in somatic organs revealed that no signals were found in leaves while a low level of expression was detected in flowers. Expression level in coma bracts was, however, remarkably high and comparable to those detected in early stages of embryogenesis.

(a)

\begin{tabular}{c|c|c|c|c|c|c|c|c} 
SP & $\begin{array}{c}\text { Leucine } \\
\text { Zipper }\end{array}$ & LRR1 LRR2 LRR3 & LRR4 LRR5 & SPP & TM & Kinase & c \\
\hline
\end{tabular}

(b)

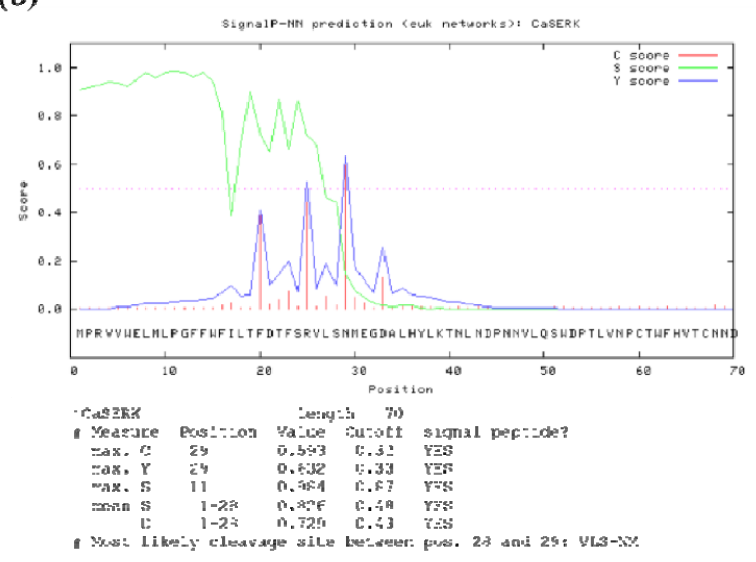

(c)

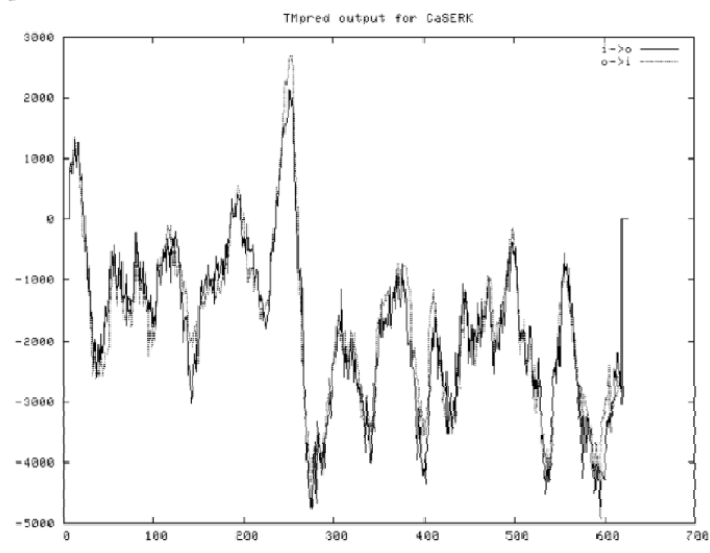

Figure 3. CaSERK sequence analysis

(a) A schematic illustration showing the organization of conserved domains in CaSERK. SP (N-terminal signal peptide), LRR (leucine-rich repeat), SPP (proline-rich SPP region containing the SPP-motif), TM (Transmembrane), kinase (kinase domains), $C$ (C-terminal domain); (b) Signal peptide sequence prediction by SignalP; (c) Transmembrane region prediction by TMpred. 


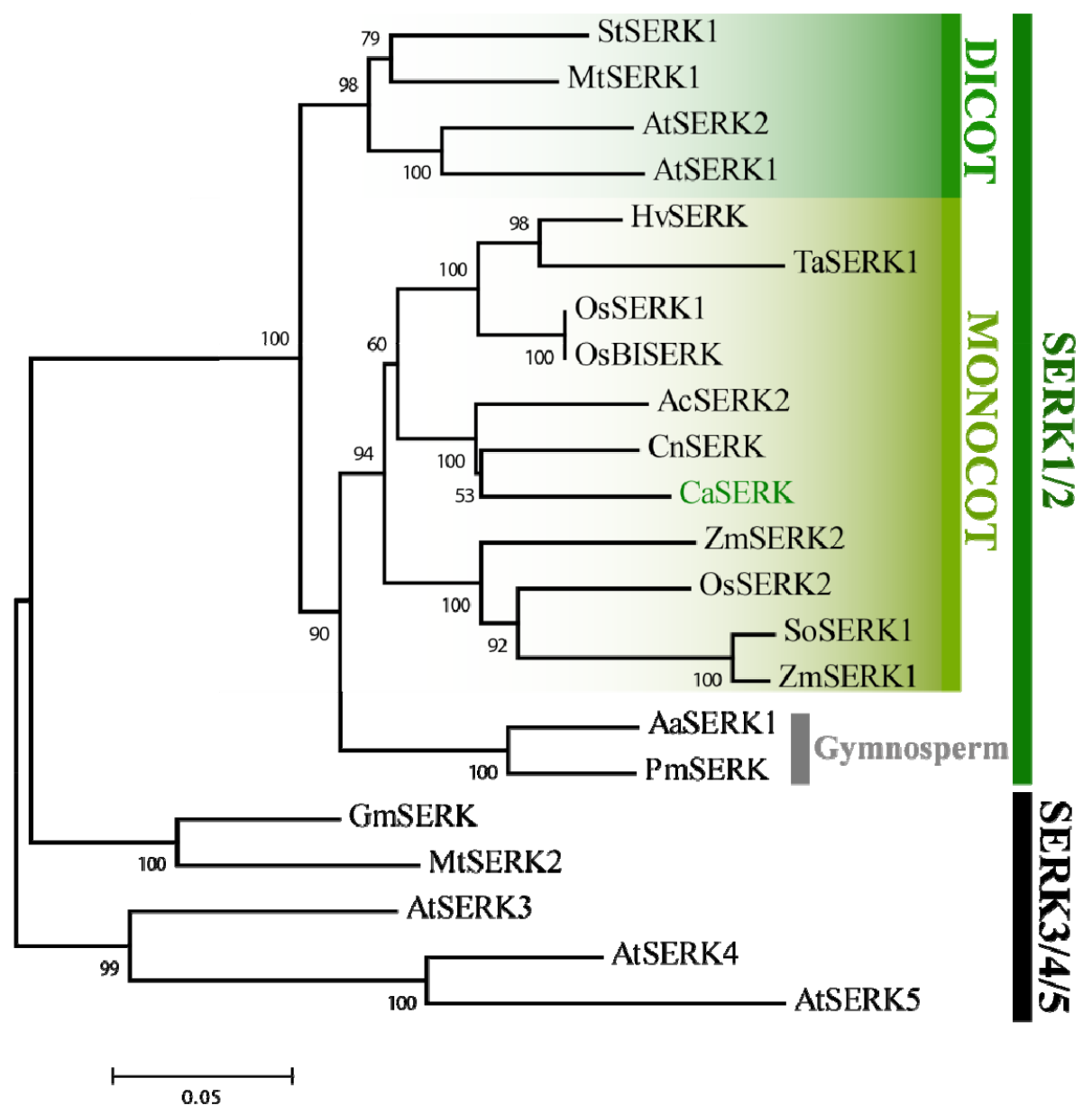

Figure 4. Phylogenetic tree constructed based on the alignment of full-length amino acid sequences indicating the evolutionary relationships among CaSERK, CnSERK (Cocos nucifera), AAV58833.2; AcSERK2 (Ananas comosus), AEC46976.1; OsSERK1 (Oryza sativa), NP_001061108.1; OsSERK2, NP_001052975.1; OsBISERK,

AAR26543.1; HvSERK (Hordeum vulgare), ABN05373.1; TaSERK1 (Triticum aestivum), ACD49737.1;

ZmSERK1 (Zea mays), NP_001105132.1; ZmSERK2, NP_001105133.1; SoSERK1 (Saccharum hybrid), ACT22809.1; MtSERK1 (Medicago truncatula), AAN64293.1; MtSERK2, ADO15291.1; StSERK1 (Solanum tuberosum), ABO14173.1; GmSERK (Glycine max), ACM89473.1; AtSERK1 (Arabidopsis thaliana), NP_177328.1; AtSERK2, NP_174683.1; AtSERK3, AAK68074.1; AtSERK4, NP_178999.2; AtSERK5, NP_179000.3; AaSERK1 (Araucaria angustifolia), ACY91853.1; PmSERK (Pinus mássoniana), ACZ56417.1. Bootstrap percentages from 1,000 replicates are shown at each node

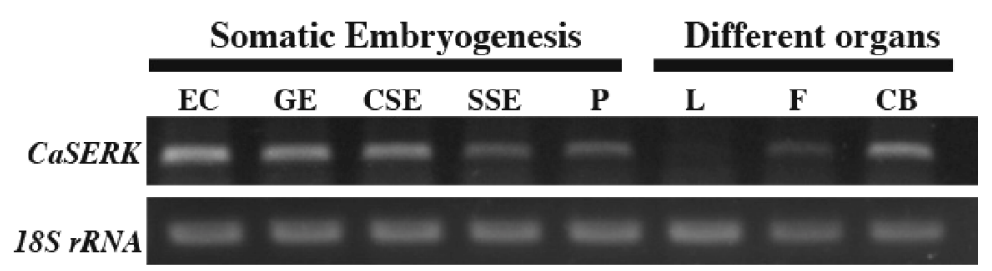

Figure 5. RT-PCR analysis of CaSERK expression at different stages of somatic embryogenesis and in different plant organs. C. alismatifolia $18 S r R N A$ gene was used as an internal control. EC (embryogenic callus), $G E$ (globular embryos), CSE (club-shaped embryos), SSE (scutellum-shaped embryos), $P$ (plantlets), $L$ (leaves), $F$ (flowers), $C B$ (coma bracts)

\section{Discussion}

In recent years, achieving high-frequency somatic embryogenesis and regeneration has become a research focus 
in many crop species as it could facilitate their rapid mass propagation, trait modification by genetic transformation as well as applications in long-term germplasm conservation. Substantial efforts have been made to uncover the regulation of somatic embryogenesis at the molecular level to gain a better view of this key process, and thus generate the possibility for the establishment of efficient regeneration system via somatic embryogenesis in the target plants.

In the present study, a full-length transcript of a SERK gene, designated as CaSERK, was isolated from well-established in vitro embryogenic cultures of Curcuma alismatifolia, a commercially valuable ornamental ginger. Analysis of the predicted amino acid sequence showed that the encoded protein is a SERK member belonging to the LRR-RLK superfamily (Walker, 1994). All the domains characteristic of the SERK proteins reported in other plant species are present in CaSERK. These include the hallmark proline-rich SPP motif which has been proposed to act as a hinge to give flexibility to the extracellular portion of the SERK protein and is not found in other plant LRR-RLKs (Hecht et al., 2001). High sequence identity to other SERKs further confirmed CaSERK identity. The deduced amino acid sequence of CaSERK shared highest similarity to SERKs in other monocots. Close relationship to other SERKs was also suggested by the placement of CaSERK in the SERK1/2 clade of the SERK phylogenetic tree. High degree of structural conservation and extensive sequence similarity suggested that CaSERK is a SERK ortholog and could share similar functions in somatic embryogenesis.

In several species, SERK expression has been linked to acquisition of embryogenic competence (Hecht et al., 2001; Thomas et al., 2004; Pérez-Núñez et al., 2009; Cueva et al., 2012; Talapatra et al., 2014). Monitoring of expression during somatic embryogenesis in in vitro cultures revealed that CaSERK was most strongly expressed in embryogenic callus. Lower levels of transcripts were detected in globular and club-shaped embryos. Expression continued in scutellum-shaped embryos and plantlets but at further reduced levels. Up-regulation of CASERK in the early stages suggested that it is involved in somatic embryogenesis initiation in Curcuma alismatifolia. However, the continuous expression of CaSERK in the subsequent embryo-transition phase and up to the plantlet stage was indicative of additional roles during development and regeneration of embryos. Transcript accumulation detected in flowers and particularly coma bracts also suggested a wider role of CaSERK in development. Studies of SERK in rice (Ito et al., 2005), maize (Baudino et al., 2001), Citrus unshiu (Shimada et al., 2005) and rose (Zakizadeh et al., 2010) have also reported a broad profile of SERK expression in various somatic tissues which suggested that $S E R K$ functions are not restricted to somatic embryogenesis. In fact, SERK genes have been implicated in a diverse array of processes such as defense responses (Hu et al., 2005; Song et al., 2008; Santos et al., 2009) and apomixis (Albertini et al., 2005; Podio et al., 2014) in addition to their notable role in somatic embryogenesis.

The identification of CaSERK is, to our knowledge, the first report of a SERK sequence in the Zingiberaceae plant family, which consists of more than 1,200 species. The expression patterns of CaSERK strongly suggest a crucial role in somatic embryogenesis. Detailed understanding of CaSERK function could offer new avenues for large-scale propagation, introduction of novel traits by gene transfer and also long-term germplasm conservation and maintenance in Curcuma alismatifolia and other members of the ginger family.

\section{Acknowledgements}

This research was supported by grants from Young Scientist and Technologist Program (YSTP, Thailand), National Science and Technology Development Agency (NSTDA, Thailand) and National Center for Genetic Engineering and Biotechnology (BIOTEC, Thailand).

\section{References}

Albertini, E., Marconi, G., Reale, L., Barcaccia, G., Proceddu, A., Ferranti, F., \& Falcinelli, M. (2005). SERK and APOSTART. Candidates genes for apomixis in Poa pratensis. Plant Physiology, 138(4), 2185-2199. http://dx.doi.org/10.1104/pp.105.062059

Baudino, S., Hansen, S., Brettschneider, R., Hecht, V. F. G., Dresselhaus, T., Lörz, H., ... Rogowsky, P. M. (2001). Molecular characterization of two novel maize LRR receptor-like kinases, which belong to the SERK gene family. Planta, 213(1), 1-10. http://dx.doi.org/10.1007/s004250000471

Cock, J. M., Vanoosthuyse, V., \& Gaude, T. (2002). Receptor kinase signalling in plants and animals: Distinct molecular systems with mechanistic similarities. Current Opinion in Cell Biology, 14(2), 230-236. http://dx.doi.org/10.1016/S0955-0674(02)00305-8

Cueva, A., Concia, L., \& Cella, R. (2012). Molecular characterization of a Cyrtochilum loxense somatic embryogenesis receptor-like kinase $(S E R K)$ gene expressed during somatic embryogenesis. Plant Cell Reports, 31(6), 1129-1139. http://dx.doi.org/10.1007/s00299-012-1236-x 
Elphinstone, J. G. (2005). The current bacterial wilt situation: A global overview. In C. Allen, P. Prior, \& A. C. Hayward (Eds.), Bacterial wilt disease and the Ralstonia solanacearum species complex (pp. 9-28). Minnesota, USA: American Phytopathological Society.

Ghosh, A., Ganapathi, T. R., Nath, P., \& Bapat, V. A. (2009). Establishment of embryogenic cell suspension cultures and Agrobacterium-mediated transformation in an important Cavendish banana cv. Robusta (AAA). Plant Cell, Tissue and Organ Culture, 97(2), 131-139. http://dx.doi.org/10.1007/s11240-009-9507-0

He, R., \& Gang, D. R. (2014). Somatic embryogenesis and Agrobacterium-mediated transformation of turmeric (Curcuma longa). Plant Cell, Tissue and Organ Culture, 116(3), 333-342. http://dx.doi.org/10.1007/s11240-013-0407-y

Hecht, V., Vielle-Calzada, J.-P., Hartog, M. V., Schmidt, E. D. L., Boutilier, K., Grossnicklaus, U., \& de Vries, S. C. (2001). The Arabidopsis SOMATIC EMBRYOGENESIS RECEPTOR KINASE 1 gene is expressed in developing ovules and embryos and enhances embryogenic competence in culture. Plant Physiology, 127(3), 803-816. http://dx.doi.org/10.1104/pp.010324

Hu, H., Xiong, L., \& Yang, Y. (2005). Rice SERK1 gene positively regulates somatic embryogenesis of cultured cell and host defense response against fungal infection. Planta, 222(1), 107-117. http://dx.doi.org/10.1007/s00425-005-1534-4

Ito, Y., Takaya, K., \& Kurita, N. (2005). Expression of SERK family receptor-like protein kinase genes in rice. Biochemica et Biophysica Acta, 1730(3), 253-258. http://dx.doi.org/10.1016/j.bbaexp.2005.06.007

Ma, J., He, Y., Wu, C., Liu, H., Hu, Z., \& Sun, G. (2012). Cloning and molecular characterization of a SERK gene transcriptionally induced during somatic embryogenesis in Ananas comosus cv. Shenwan. Plant Molecular Biology Reporter, 30(1), 195-203. http://dx.doi.org/10.1007/s11105-011-0330-5

Maillot, P., Label, S., Schellenbaum, P., Jacques, A., \& Walter, B. (2009). Differential regulation of SERK, LEC1-like and Pathogenesis-Related genes during indirect secondary somatic embryogenesis in grapevine. Plant Physiology and Biochemistry, 47(8), 743-752. http://dx.doi.org/10.1016/j.plaphy.2009.03.016

Murashige, T., \& Skoog, F. (1962). A revised medium for rapid growth and bioassays with tobacco tissue cultures. Physiologia Plantarum, 15(3), 473-497. http://dx.doi.org/10.1111/j.1399-3054.1962.tb08052.x

Nolan, K. E., Irwanto, R. R., \& Rose, R. J. (2003). Auxin up-regulates MtSERK1 expression in both Medicago truncatula root-forming and embryogenic cultures. Plant Physiology, 133(1), 218-230. http://dx.doi.org/10. 1104/pp.103.020917

Pérez-Núñez, M. T., Souza, R., Sáenz, L., Chan, J. L., Zúñiga-Aguilar, J. J., \& Oropeza, C. (2009). Detection of a $S E R K$-like gene in coconut and analysis of its expression during the formation of embryogenic callus and somatic embryos. Plant Cell Reports, 28(1), 11-19. http://dx.doi.org/10.1007/s00299-008-0616-8

Podio, M., Felitti, S. A., Siena, L. A., Delgado, L., Mancini, M., Seijo, J. G., ... Ortiz, J. P. A. (2014). Characterization and expression analysis of SOMATIC EMBRYOGENESIS RECEPTOR KINASE (SERK) genes in sexual and apomictic Paspalum notatum. Plant Molecular Biology, 84(4-5), 479-495. http://dx.doi. org/10.1007/s11103-013-0146-9

Prathepha, P. (2000). Screening of random primer to evaluate DNA diversity in Thai Curcuma using random amplified polymorphic DNAs. Songklanakarin Journal of Science and Technology, 22(1), 8-13.

Raju, C. S., Kathiravan, K., Aslam, A., \& Shajahan, A. (2013). An efficient regeneration system via somatic embryogenesis in mango ginger (Curcuma amada Roxb.). Plant Cell, Tissue and Organ Culture, 112(3), 387-393. http://dx.doi.org/10.1007/s11240-012-0244-4

Santos, M. O., Romano, E., Vieira, L. S., Baldoni, A. B., \& Aragão, F. J. L. (2009). Suppression of SERK gene expression affects fungus tolerance and somatic embryogenesis in transgenic lettuce. Plant Biology, 11(1), 83-89. http://dx.doi.org/10.1111/j.1438-8677.2008.00103.x

Schmidt, E. D. L., Guzzo, F., Toonen, M. A. J., \& de Vries, S. C. (1997). A leucine-rich repeat containing receptor-like kinase marks somatic plant cells competent to form embryos. Development, 124(10), 2049-2062.

Shah, K., Vervoort, J., \& de Vries, S. C. (2001). Role of threonines in the Arabidopsis thaliana Somatic Embryogenesis Receptor Kinase 1 activation loop in phosphorylation. Journal of Biological Chemistry, 276(44), 41263-41269. http://dx.doi.org/10.1074/jbc.M102381200

Shimada, T., Hirabayashi, T., Endo, T., Fujii, H., Kita, M., \& Omura, M. (2005). Isolation and characterization of 
the somatic embryogenesis receptor-like kinase gene homologue (CitSERK1) from Citrus unshiu Marc. Scientia Horticulturae, 103(2), 233-238. http://dx.doi.org/10.1016/j.scienta.2004.07.005

Singla, B., Khurana, J. P., \& Khurana, P. (2008). Characterization of three somatic embryogenesis receptor kinase genes from wheat, Triticum aestivum. Plant Cell Reports, 27(5), 833-843. http://dx.doi.org/10.1007/s00299-008-0505-1

Song, D., Li, G., Song, F., \& Zheng, Z. (2008). Molecular characterization and expression analysis of OSBISERK1, a gene encoding a leucine-rich repeat receptor-like kinase, during disease resistance responses in rice. Molecular Biology Reports, 35(2), 275-283. http://dx.doi.org/10.1007/s11033-007-9080-8

Steiner, N., Santa-Catarina, C., Guerra, M. P., Cutri, L., Dornelas, M. C., \& Floh, E. I. S. (2012). A gymnosperm homolog of somatic embryogenesis receptor-like kinase-1 (SERK1) is expressed during somatic embryogenesis. Plant Cell, Tissue and Organ Culture, 109(1), 41-50. http://dx.doi.org/10.1007/s11240-011-0071-z

Talapatra, S., Ghoshal, N., \& Raychaudhuri, S. S. (2014). Molecular characterization, modeling and expression analysis of a somatic embryogenesis receptor kinase (SERK) gene in Momordica charantia L. during somatic embryogenesis. Plant Cell, Tissue and Organ Culture, 116(3), 271-283. http://dx.doi.org/10.1007/s11240-013-0401-4

Thomas, C., Meyer, D., Himber, C., \& Steinmetz, A. (2004). Spatial expression of a sunflower SERK gene during induction of somatic embryogenesis and shoot organogenesis. Plant Physiology and Biochemistry, 42(1), 35-42. http://dx.doi.org/10.1016/j.plaphy.2003.10.008

Walker, J. C. (1994). Structure and function of the receptor-like protein kinases of higher plants. Plant Molecular Biology, 26(5), 1599-1609. http://dx.doi.org/10.1007/BF00016492

Zakizadeh, H., Stummann, B. M., Lütken, H., \& Müller, R. (2010). Isolation and characterization of four somatic embryogenesis receptor-like kinase (RhSERK) genes from miniature potted rose (Rosa hybrida cv. Linda). Plant Cell, Tissue and Organ Culture, 101(3), 331-338. http://dx.doi.org/10.1007/s11240-010-9693-9

\section{Copyrights}

Copyright for this article is retained by the author(s), with first publication rights granted to the journal.

This is an open-access article distributed under the terms and conditions of the Creative Commons Attribution license (http://creativecommons.org/licenses/by/3.0/). 